\title{
PSYCHE.
}

\section{NOTES ON HYBRIDS OF SAMIA CYNTHIA AND ATTACUS PROMETHEA.}

CAROLINE GRAY SOULE, BROOKLINE, MASS.

Having been told that it was difficult, if not impossible, to obtain fertile eggs from cross-mating these species I carefully watched the normal mating of both species for suggestions which should help in obtaining hybrids.

I found that the males were so excited by the odor of the females that they would fasten their claspers on any part of a female's body or even on each other. Therefore I put female cynthias in a cage toward which the wind blew from a cage containing a female promethea, and introduced male prometheas. After a few minutes of the wild flight and quivering of the wings characteristic of the mating of promethea the males mated the cynthia females as readily as if they had been of their own species.

The same experiment was tried with cynthia males and promethea females and with equal success so far as mating went.

Of the eggs I sent away more than three fourths and of these I know the results of those sent Miss Eliot only.

Only two of my eggs laid by cynthia females hatched, and the larvae were normal cynthia larvae except that in the last stage they were greener.

Of the eggs laid by promethea females all mine and Miss Eliot's hatched and gave great variety, though we divided them into "the promethea form" and "the cynthia form," for convenience in referring to them.

There were more of the "promethea form" and these were normal promethea larvae except that in the last stage some had very noticeable blue patches around the black dots of the lateral and stigmatal rows. Rearing them side by side with a brood of normal, pure prometheas I could see no other difference.

The "cynthia form" larvae were like the prometheas in the first two stages, but after the second moult they could be separated from those, though they varied among themselves.

Their heads were yellow barred with black. Some bodies were yellow with transverse black lines, black tubercles on the first two and anal segments, and yellow tubercles elsewhere. The legs were black, the props yellow.

Others had two yellow tubercles, 
rather larger, on the third segment and one bifid, larger, yellow tubercle on the eleventh segment. Part of the dorsal tubercles, on the abdominal segments, were yellow, part black, and part were yellow ringed with black. There was no regularity in the distribution of coloring, the yellow tubercles being sometimes on one side, sometimes on both, sometimes opposite, sometimes at one end, sometimes at the other, sometimes more on one side than on the other.

After the third moult the head was yellow with two black spots, and sometimes two black dots. The body was almost white, the first and last segments being yellow. The first segment had six black tubercles, shaped like cynthia's; the second segment had two large yellow tubercles ringed with black on the dorsum and two smaller black ones on each side; the third segment had two large yellow dorsal, and four smaller yellow tubercles ringed with black, and the abdominal segments were like this except the eleventh which had one large dorsal tubercle of yellow, and the other four tubercles smaller, yellow ringed with black; and the anal segment which had two rather large tubercles, yellow ringed with black, on the dorsum, one black one on each side below these, and two black ones on the anal plate. The legs were yellow, the props yellow with a black spot, except the anal props which had the black triangle characteristic of promethea.

One larva had the dorsal tubercles on the second segment smooth and shaped like those of promethea, the others had these tubercles like cynthia's.

After the fourth moult the head was small, yellow with two small black marks, and in one case a black bar across it. The body was pale blue-green with white bloom, except the first and anal segments, the former being yellow, the latter very yellow green like that of promethea. The dorsal tubercles on every segment were long and shaped like promethea's thoracic tubercles in most cases, though a few had abdominal dorsal tubercles shaped like cynthia's. These dorsal tubercles varied much in color, some being pale coral-red, darker on the thoracic segments and growing paler to the eleventh segment; others being pale red on the first six segments, yellow elsewhere; others pale red on a few segments and green with yellow tops on the rest. Some had the thoracic dorsal tubercles ringed with black at base, others had all the dorsal tubercles so ringed; while others had black rings irregularly distributed, not even on opposite tubercles on some segments.

The other tubercles were like cynthia's, pale blue ringed with black. The legs and props were yellow with a black dot on each. Two had the anal plate edged with pale blue, like cynthia's, and one had this edge almost purple.

One larva had the dorsal tubercles, from the eighth to the anal segment, pale coral-red at tip and vivid yellowgreen at base, and the two dorsal tubercles at the top of the anal plate vivid green with a broad black ring on each. 
At this stage many died from a disease which killed also many of my excoecatus and all my promethea larvae, and many of Miss Eliot's hybrids in Nonquitt.

The "promethea form" spun after the fourth moult, but most of the "cynthia form" moulted a fifth time.

After this moult they were like the last stage, but much greener and with much less bloom.

In this stage more died from the same disease, though each was given a tin by itself.

It is not possible to give in writing any adequate idea of the variety or the beauty of this "cynthia form." Both forms came from eggs laid by the same moth and kept separate from other eggs laid after similar mating.

I think that anyone can obtain fertile eggs of hybrids of Attacine moths by following my plan of arranging the cages for mating, although every coition may not result in fertile eggs.

Eggs laid by a female cynthia which I found out of doors mated with a male A. cecropia failed to give larvae, as did eggs laid by cynthia females mated with promethea males.

\section{GROUP CHARACTERISTICS OF SOME NORTH AMERICAN BUT- TERFLIES - V.}

BY SAMUEL H. SCUDDER, CAMBRIDGE, MASS.

Apostraphia Hübner.

Caterpillar at birth: All the tubercles rounded conical, one to a segment in each row but the infrastigmatal where there are two, three rows on each side besides a supralateral series with appendages less than half as long as the others. Mature caterpillar: Head covered with a pair of slender, tapering, slightly recurved spines. Each side of body with three rows of very long and slender straight, very scantily bristled spines, those of the upper rows equal and half as long again as the segments. Chrys. alis: Body with strong laminate protuberances, the frontal pair excessively elongate, widely divergent, ribbon-like and serrate; antennal joints conspicuously spined; third abdominal segment and the adjoining segments to some extent with it with a laminate laterodorsal flange crowned as the other abdominal tubercles with slender aciculate spines.

Apostraphia charithonia L. (Heliconia charitonia Auct.). Butterfy: Wings rich blackish brown above, a little paler below. Fore wings crossed by three narrow yellow stripes, the middle one running obliquely from costa, past the tip of cell toward the middle of the outer border; another subparallel to it midway to the tip of wing; the third following the black median vein to its first fork and here bent abruptly parallel to the others. Hind wings with a rather narrow 

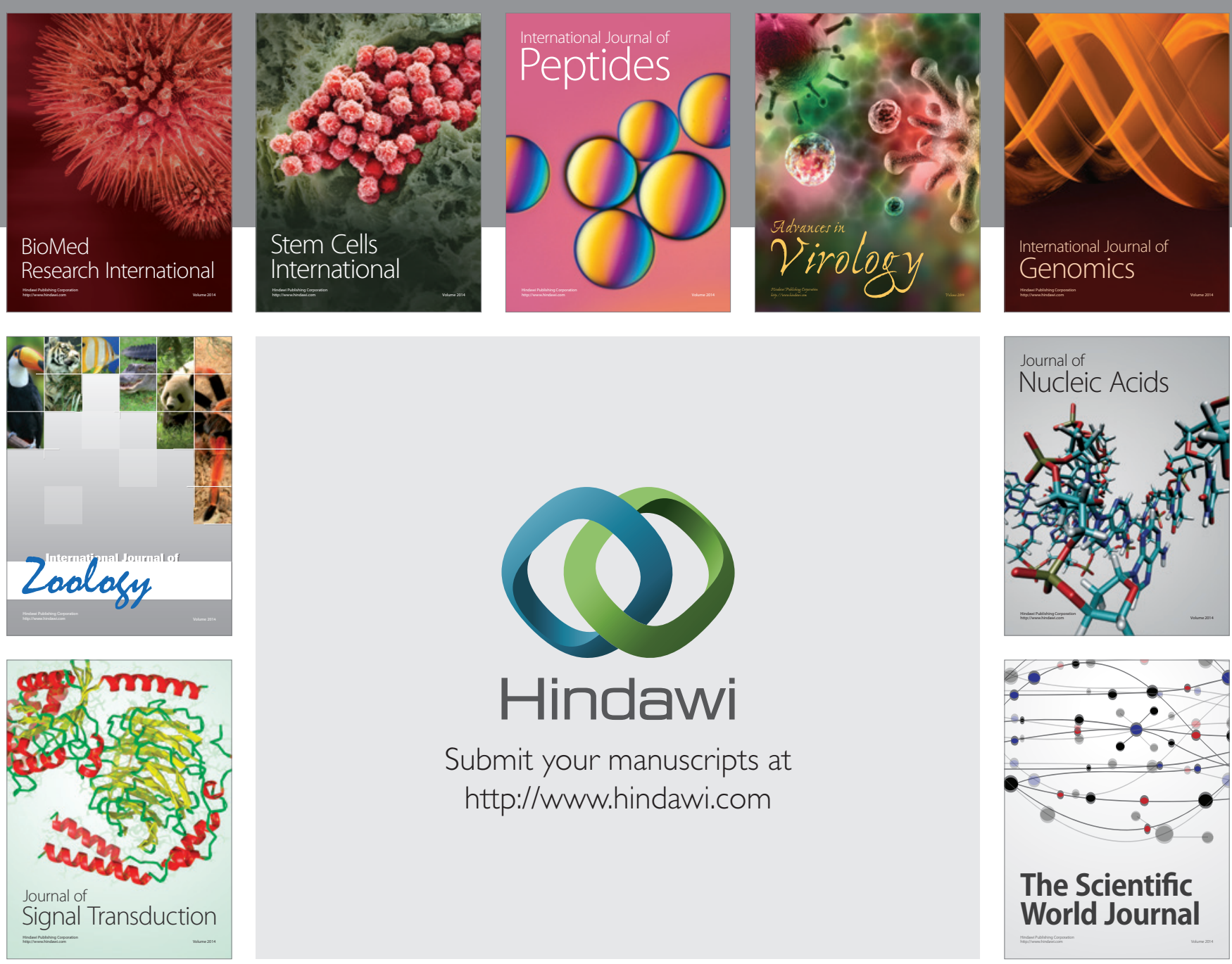

Submit your manuscripts at

http://www.hindawi.com
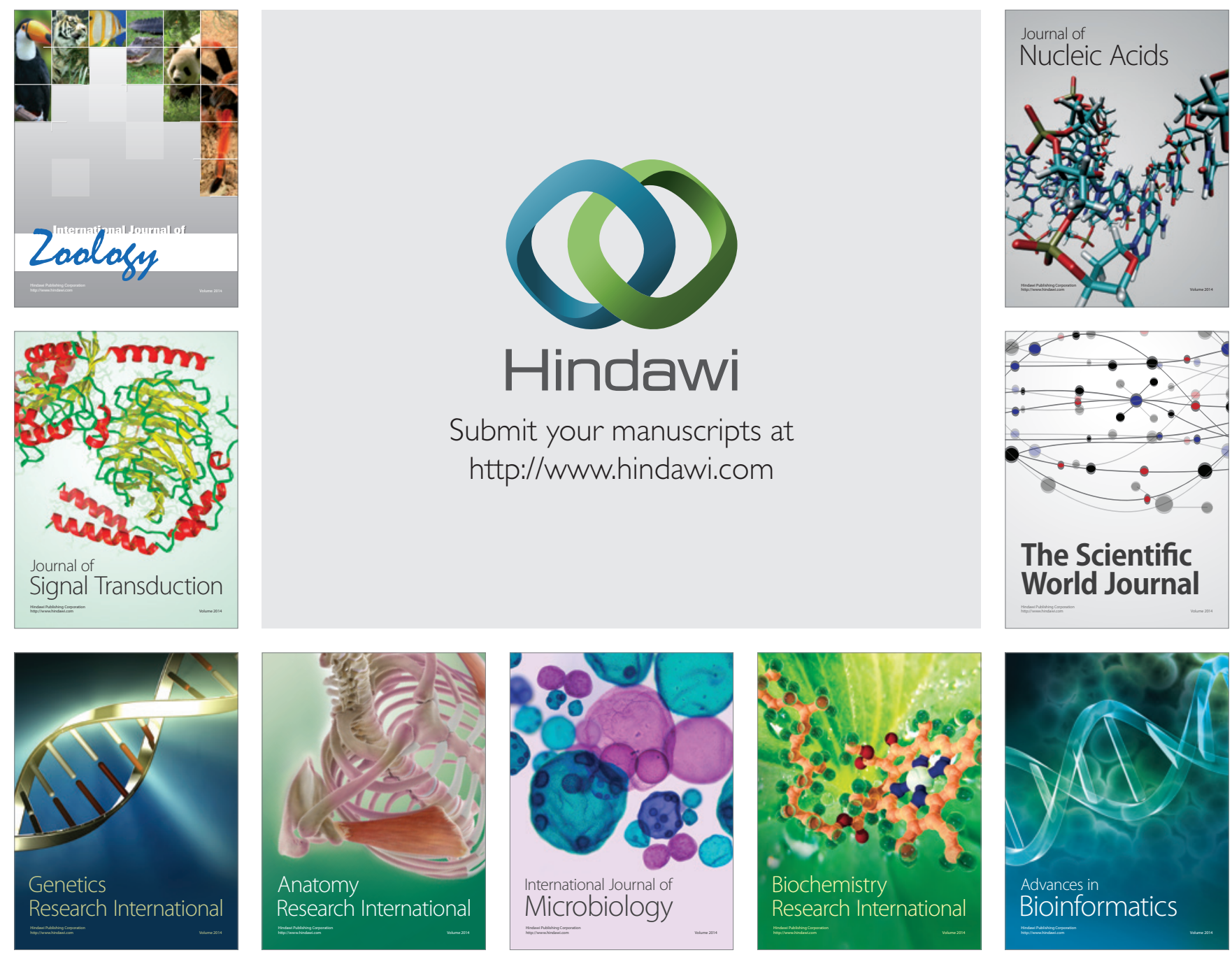

The Scientific World Journal
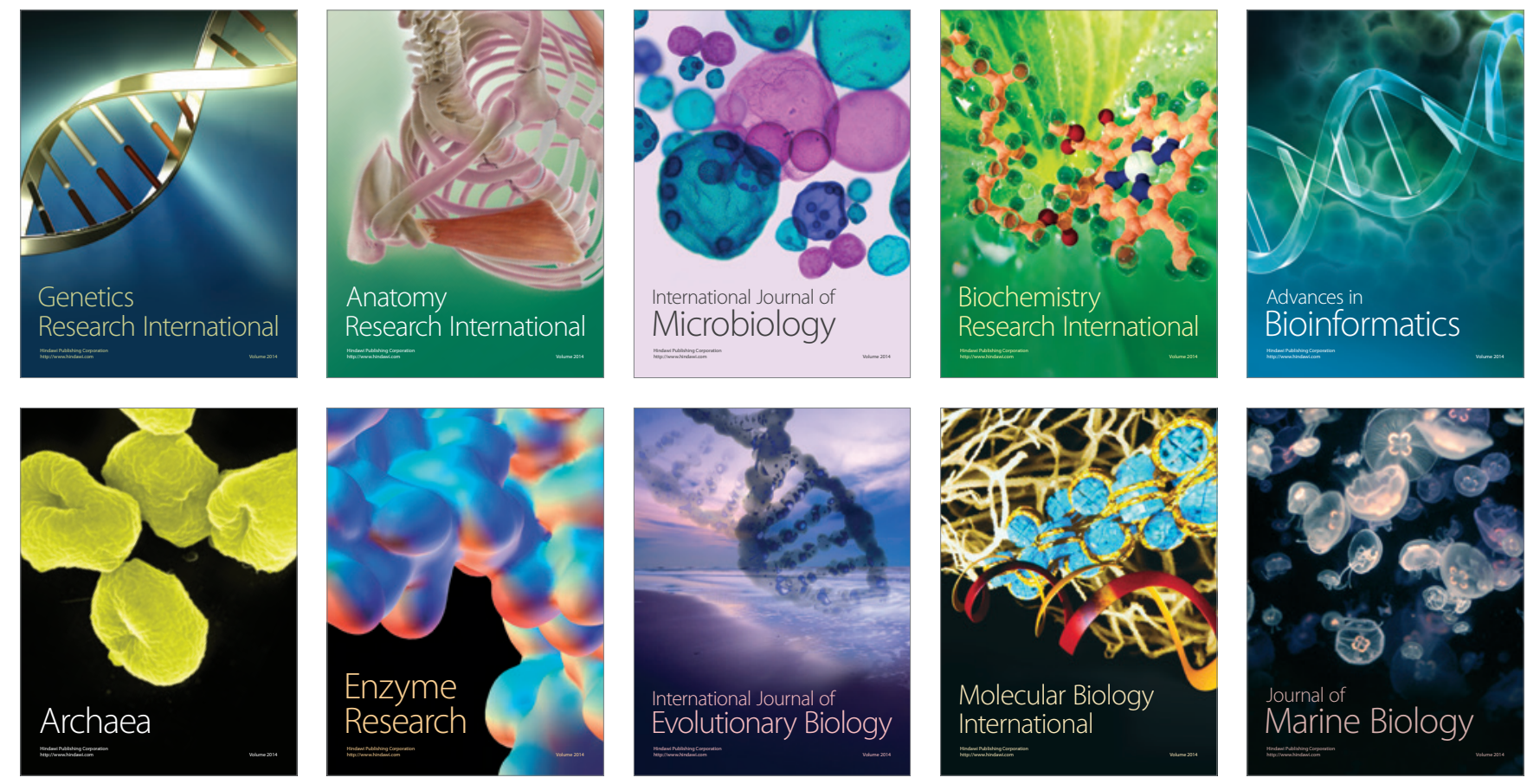